\title{
Novel Betacoronavirus in Dromedaries of the Middle East, 2013
}

\author{
Patrick C.Y. Woo, ${ }^{1}$ Susanna K.P. Lau, ${ }^{1}$ Ulrich Wernery, Emily Y.M. Wong, Alan K.L. Tsang, \\ Bobby Johnson, Cyril C.Y. Yip, Candy C.Y. Lau, Saritha Sivakumar, Jian-Piao Cai, Rachel Y.Y. Fan, \\ Kwok-Hung Chan, Ringu Mareena, and Kwok-Yung Yuen
}

In 2013, a novel betacoronavirus was identified in fecal samples from dromedaries in Dubai, United Arab Emirates. Antibodies against the recombinant nucleocapsid protein of the virus, which we named dromedary camel coronavirus (DcCoV) UAE-HKU23, were detected in $52 \%$ of 59 dromedary serum samples tested. In an analysis of 3 complete DcCoV UAE-HKU23 genomes, we identified the virus as a betacoronavirus in lineage A1. The DcCoV UAE-HKU23 genome has $\mathrm{G}+\mathrm{C}$ contents; a general preference for $\mathrm{G} / \mathrm{C}$ in the third position of codons; a cleavage site for spike protein; and a membrane protein of similar length to that of other betacoronavirus A1 members, to which DcCoV UAEHKU23 is phylogenetically closely related. Along with this coronavirus, viruses of at least 8 other families have been found to infect camels. Because camels have a close association with humans, continuous surveillance should be conducted to understand the potential for virus emergence in camels and for virus transmission to humans.

$\mathrm{T}$ he 2003 epidemic of severe acute respiratory syndrome (SARS) boosted interest in the discovery of new coronaviruses (CoVs) (1-3). In 2004, a novel human $\mathrm{CoV}(\mathrm{HCoV})$, named HCoV-NL63, was reported (4), and the discovery of another novel HCoV, HCoV-HKU1, was described and further characterized in 2005 (5,6) and 2006 (7). SARS-CoV-like viruses have also been reported in Chinese horseshoe bats in Hong Kong, China, and other horseshoe bats in China $(8,9)$. The discovery in Chinese horseshoe bats in Yunnan, China, of a new SARS-CoV-

Author affiliations: The University of Hong Kong, Hong Kong, China (P.C.Y. Woo, S.K.P. Lau, E.Y.M. Wong, A.K.L. Tsang, C.C.Y. Yip, C.C.Y. Lau, J.-P. Cai, R.Y.Y. Fan, K.H. Chan, K.-Y. Yuen); and Central Veterinary Research Laboratory, Dubai, United Arab Emirates (U. Wernery, B. Johnson, S. Sivakumar, R. Mareena)

DOI: http://dx.doi.org/10.3201/eid2004.131769 like virus that uses ACE2 as receptor has furthered interest in discovering animal origins of human infections (10). We have discovered 20 other animal CoVs that include 2 novel betacoronavirus lineages and a novel genus, Deltacoronavirus (11-20). From our studies, bats and birds were shown to be the gene sources for fueling the evolution and dissemination of alphacoronaviruses and betacoronaviruses and of gammacoronaviruses and deltacoronaviruses, respectively (18).

In 2012, a novel CoV, Middle East respiratory syndrome CoV (MERS-CoV) emerged as a cause of severe respiratory infections associated with high rates of death among humans; the virus is closely related to tylonycteris bat CoV HKU4 and pipistrellus bat CoV HKU5 (Pi-Bat CoV HKU5) (21-23). It has also been shown that dromedaries in the Middle East possess MERS-CoV neutralizing antibodies (24). To further knowledge of the evolution and dissemination of CoVs, we conducted a molecular epidemiology study of fecal samples obtained from dromedaries in Dubai, United Arab Emirates.

\section{Materials and Methods}

\section{Samples}

Dromedary fecal and serum samples used in the study were leftover specimens that had been submitted for pathogen screening (feces) or preventive health screening (serum) to Central Veterinary Research Laboratory (Dubai, United Arab Emirates) during January-July 2013. The fecal and serum samples were not obtained from the same animals. None of the dromedaries tested were known to have had contact with bats or horses.

We tested a total of 293 fecal samples: 232 from teenage and adult dromedaries (Camelus dromedarius) $(\geq 1$

\footnotetext{
${ }^{1}$ These authors contributed equally to this article.
} 
year of age) and 61 from dromedary calves $(<1$ year of age). Among the 293 samples, 6 were collected in January, 209 in February, 5 in March, 39 in April, 16 in May, 7 in June, and 11 in July 2013.

We tested a total of 59 serum samples: 55 from teenage and 4 from adult dromedaries. The serum samples were collected from female dairy farm or racing dromedaries. The dairy dromedaries were purchased from various countries (e.g., Saudi Arabia, Oman, Sudan, and Pakistan); the number of dairy dromedaries from each country and their lengths of stay in Dubai were not known. The racing dromedaries were from Dubai Emirate.

\section{RNA Extraction, Reverse Transcription PCR, and DNA Sequencing}

Viral RNA extraction was conducted as described $(20,23)$. Initial $\mathrm{CoV}$ screening was performed by amplifying a 440-bp fragment of CoV RNA-dependent RNA polymerase (RdRp) gene by using conserved primers (5'-GGTTGGGACTATCCTAAGTGTGA-3' and 5'-ACCATCATCNGANARDATCATNA-3' and degenerative bases $N, R$, and $D$, representing $A / C / T / G, A / G$, and $A / G / T$, respectively. After the novel $\mathrm{CoV}$ was detected in samples, subsequent screening was performed by using specific primers 5'-ACTATGACTGGCAGAATGTT-3' and 5'-TAATAAGGCGACGTAACATA-3'. To amplify a 126-bp fragment of RdRp gene, reverse transcription PCR (RT-PCR) and DNA sequencing were performed as described $(20,23)$.

\section{Virus Culture}

The fecal samples from 3 dromedaries tested positive for CoV. These samples were cultured in HRT-18G, Vero E6, Caco-2, and LLC-MK2 cell lines.

\section{Complete Genome Sequencing and Analysis}

Three complete genomes of DcCoV UAE-HKU23 $(265 \mathrm{~F}, 362 \mathrm{~F}$, and $368 \mathrm{~F})$ were amplified and sequenced as described $(5,12)$. RNA extracted from fecal specimens was used as template, and a database of $\mathrm{CoV}$ genes and genomes (CoVDB, http://covdb.microbiology.hku.hk) (25) was used for sequence retrieval. Sequences were assembled and edited to produce final sequences.

We used EMBOSS Needle (http://www.ebi.ac.uk/ Tools/psa/emboss_needle/) to compare the nucleotide sequences of the genomes and the deduced amino acid sequences with those for other CoVs. A neighbor-joining phylogenetic tree with 1,000 bootstraps was constructed by using the Jones-Taylor-Thornton substitution model; gamma distribution among sites was conducted in MEGA5 (26).

\section{Real-time Quantitative RT-PCR}

According to our protocol $(19,20)$, all samples positive for DcCoV UAE-HKU23 by RT-PCR were subjected to quantitative RT-PCR (qRT-PCR).The assay was performed, as described (27), using a realtime 1-step qRT-PCR with DcCoV UAE-HKU23 primers 5'-ATAGCGGCTACACGTGGTGTT-3' and 5'-TCCCAGCCGCCATAAAACT-3' and probe 5'(FAM) CTGTTGTTATAGGCACCACT (BHQ1)-3'. To generate calibration curves, we prepared a series of $6 \log _{10}$ dilutions equivalent to $10^{1}-10^{6}$ copies per reaction mixture and ran them in parallel with the test samples.

\section{Cloning and Purification}

The nucleocapsid proteins of SARS-CoV (betacoronavirus lineage $\mathrm{B}$ ), Pi-Bat CoV HKU5 (betacoronavirus lineage $\mathrm{C}$ ), and rousettus bat coronavirus (Ro-BatCov HKU9; betacoronavirus lineage $\mathrm{D})$ were obtained as described $(2,16)$. To produce a plasmid for DcCoV UAE-HKU23 nucleocapsid protein purification, primers 5'-CATGCCATGGGCATGTCTTTTACTCCTGGTAAGC-3' and 5'CCGCTCGAGTATTTCTGAGGTGTTTTCAG-3' were used to amplify the gene encoding the nucleocapsid protein of DcCoV UAE-HKU23. The sequence encoding aa 1-672 of the nucleocapsid protein was amplified and cloned into the $\mathrm{NcoI}$ and $\mathrm{XhoI}$ sites of expression vector pET-28b(+) (Merck KGaA, Darmstadt, Germany). Recombinant nucleocapsid protein was expressed and purified by using the $\mathrm{Ni}^{2+}-$ loaded HiTrap Chelating System (GE Healthcare Life Sciences, Little Chalfont, UK) according to the manufacturer's instructions. The nucleocapsid protein of MERS-CoV was cloned and purified by using the method described above with primers 5'-GGAATTCCATATGATGGCATCCCCTGCTGCACCTC-3' and 5'-ATAAGAATGCGGCCGCATCAGTGTTAACATCAATCATT-3'.

\section{Western Blot Analysis}

Western blot analysis was performed as described (5) with $1.5 \mu \mathrm{g}$ of purified (His) -tagged recombinant nucleocapsid protein of DcCoV UAE-HKU23 and 1:2,000, $1: 4,000$, and $1: 8,000$ dilutions of dromedary serum samples. Antigen-antibody interaction was detected by using 1:4,000 diluted horseradish peroxidase-conjugated Goat Anti-Llama IgG (Life Technologies, Carlsbad, CA, USA) and the ECL fluorescence system (GE Healthcare Life Sciences).

To determine the possibility of cross-reactivity between antibodies against the nucleocapsid protein of DcCoV UAE-HKU23 and that of other betacoronavirus lineages, we tested 3 serum samples that were positive for antibody against the nucleocapsid protein of DcCoV UAE-HKU23. We used $1.5 \mu \mathrm{g}$ of purified (His) ${ }_{6}^{-}$ tagged recombinant nucleocapsid protein of 3 betacoronaviruses (SARS-CoV [lineage B], Pi-BatCoV HKU5 [lineage C], and Ro-BatCoV HKU9 [lineage D]) and 1:2,000 dilutions of serum samples. To determine the presence of antibodies against the nucleocapsid protein 
of MERS-CoV, we tested the serum samples by using 1.5 $\mu \mathrm{g}$ of purified (His) ${ }_{6}$-tagged recombinant nucleocapsid protein of MERS-CoV and 1:2,000 dilutions of serum samples. Antigen-antibody interaction was detected as described above.

\section{Indirect Immunofluorescence}

Anti-MERS-CoV antibody detection by indirect immunofluorescence was performed as described (28) with minor modifications. In brief, Vero cells infected with MERS-CoV were prepared as described (28). Camel serum samples were screened at a dilution of 1:160 on infected and noninfected control cells. Antigen-antibody interaction was detected by using fluorescein isothiocyanate-conjugated Goat Anti-Llama IgG (Life Technologies). Serum samples positive at a screening dilution of 1:160 were further titrated with serial 2-fold dilutions. The indirect immunofluorescence antibody titer was the highest dilution giving a positive result.

\section{Neutralization Antibody Test}

The neutralization antibody test was performed as described (28). In brief, starting with a serum dilution of $1: 10$, we prepared serial 2 -fold dilutions of serum in 96well microtiter plates. For each serum dilution, $0.05 \mathrm{~mL}$ of the dilution was mixed with $0.05 \mathrm{~mL}$ of 200 MERS-CoV $50 \%$ tissue culture infectious doses and incubated at $37^{\circ} \mathrm{C}$ for $1.5 \mathrm{~h}$ in a $\mathrm{CO}_{2}$ incubator. Then $0.1 \mathrm{~mL}$ of virus-serum mixture was inoculated in duplicate wells of 96-well microtiter plates with preformed monolayers of Vero cells and further incubated at $37^{\circ} \mathrm{C}$ for 3-4 days. Cytopathic effects were observed by using an inverted microscope on days 3 and 4 after inoculation. The neutralizing antibody titer was determined as the highest dilution of serum that completely suppressed the cytopathic effects in at least half of the infected wells.

\section{Estimation of Substitution Rates and Divergence Dates}

The number of synonymous substitutions per synonymous site, $K s$, and the number of nonsynonymous substitutions per nonsynonymous site, $K a$, for each coding region between each pair of strains were calculated by using the Nei-Gojobori method (Jukes-Cantor) in MEGA5 (26). Divergence time was calculated on the basis of RdRp gene sequence data by using a Bayesian Markov Chain Monte Carlo approach as implemented in BEAST version 1.8.0 (http://beast.bio.ed.ac.uk), as described $(15,19,29,30)$. Bayesian skyline under a relaxed-clock model with an uncorrelated exponential distribution was adopted for making inferences because Bayes factor analysis for the RdRp gene indicated that this model fitted the data better than other models tested.

\section{Results}

\section{Identification of CoV in Dromedaries}

Of the 293 fecal samples tested, 14 (4.8\%) were RTPCR positive for the CoV RdRp gene; $1(0.4 \%)$ of the samples was from an adult dromedary and 13 (21.3\%) were from calves (Table 1). Of the 14 positive samples, 11 were collected in April and 3 were collected in May. Ten of the 14 samples were submitted to the Central Veterinary Research Laboratory for routine checking, and the other 4 were collected because the dromedaries had diarrhea. Sequencing results indicated a 126-nt sequence identical to that of equine $\mathrm{CoV}$, a betacoronavirus 1 species in lineage A (betacoronavirus A1).

\section{Virus Culture and Virus Load}

Attempts to stably passage DcCoV UAE-HKU23 in cell cultures were unsuccessful; no cytopathic effect or viral replication was detected. Real-time qRT-PCR showed that the amounts of DcCoV UAE-HKU23 RNA ranged from $5.7 \times 10^{4}$ copies $/ \mathrm{mL}$ to $9.8 \times 10^{7}$ copies $/ \mathrm{mL}$ (median $\left.8.4 \times 10^{5}\right)$ in the 14 fecal samples positive for $\mathrm{DcCoV}$ UAE-HKU23 (Table 1).

\section{Genome Organization and Coding Potential}

The 3 complete genomes of DcCoV UAE-HKU23 (GenBank accession nos. KF906249-KF906251) were 31,036 bases and had a $\mathrm{G}+\mathrm{C}$ content of $37 \%$ (Table 2 ). The genome organization is similar to that of other betacoronavirus lineage A CoVs (Figure 1). Additional openreading frames (ORFs) coding for nonstructural proteins (NSPs) NS2 and NS5 are found. DcCoV UAE-HKU23 and other CoVs in betacoronavirus lineage A possess the same putative transcription regulatory sequence motif, 5'-UCUAAAC-3', at the $3^{\prime}$ end of the leader sequence and preceding most ORFs (Table 3; online Technical

\begin{tabular}{|c|c|c|}
\hline Age category & Reason for sample testing & Virus load \\
\hline Calf & Routine check & $3.3 \times 10^{6}$ \\
\hline Calf & Routine check & $1.1 \times 10^{6}$ \\
\hline Calf & Routine check & $1.5 \times 10^{5}$ \\
\hline Calf & Routine check & $3.4 \times 10^{5}$ \\
\hline Calf & Routine check & $3.2 \times 10^{6}$ \\
\hline Calf & Routine check & $6.5 \times 10^{5}$ \\
\hline Calf & Routine check & $9.5 \times 10^{5}$ \\
\hline Calf & Routine check & $5.7 \times 10^{4}$ \\
\hline Calf & Routine check & $2.1 \times 10^{5}$ \\
\hline Calf & Routine check & $4.4 \times 10^{5}$ \\
\hline Adult & Diarrhea & $7.3 \times 10^{5}$ \\
\hline Calf & Diarrhea & $9.8 \times 10^{7}$ \\
\hline Calf & Diarrhea & $4.4 \times 10^{7}$ \\
\hline Calf & Diarrhea & $1.0 \times 10^{7}$ \\
\hline
\end{tabular}


Table 2. Comparison of representative coronaviruses with a novel betacoronavirus, DcCoV UAE-HKU23, discovered in dromedaries in the Middle East, 2013*

\begin{tabular}{|c|c|c|c|c|c|c|c|}
\hline \multirow[b]{2}{*}{ Coronavirus (genome) } & \multicolumn{2}{|c|}{ Genome features } & \multicolumn{5}{|c|}{ \% Pairwise amino acid identity with DcCoV UAE-HKU23 (265F) } \\
\hline & Size, bases & $\mathrm{G}+\mathrm{C}$ content & $3 \mathrm{CL}^{\text {pro }}$ & RdRp & Helicase & S protein & $\mathrm{N}$ protein \\
\hline \multicolumn{8}{|l|}{ Alphacoronavirus } \\
\hline HCoV-229E & 27,317 & 0.38 & 44.4 & 55.8 & 57.9 & 26.9 & 25.1 \\
\hline HCoV-NL63 & 27,553 & 0.34 & 42.8 & 56.0 & 57.5 & 26.4 & 24.1 \\
\hline \multicolumn{8}{|l|}{ Betacoronavirus } \\
\hline \multicolumn{8}{|l|}{ Lineage $A$} \\
\hline $\mathrm{BCoV}$ & 31,028 & 0.37 & 99.7 & 99.9 & 99.5 & 94.1 & 98.4 \\
\hline SACoV & 30,995 & 0.37 & 99.7 & 99.8 & 99.3 & 94.1 & 98.9 \\
\hline DcCoV UAE-HKU23 (362F) & 31,036 & 0.37 & 99.7 & 100 & 100 & 99.8 & 100 \\
\hline DcCoV UAE-HKU23 (368F) & 31,036 & 0.37 & 99.7 & 100 & 100 & 99.8 & 100 \\
\hline \multicolumn{8}{|l|}{ Lineage B } \\
\hline SARS-CoV & 29,751 & 0.41 & 48.4 & 66.3 & 68.0 & 30.4 & 34.4 \\
\hline \multicolumn{8}{|l|}{ Lineage $\mathrm{C}$} \\
\hline MERS-CoV & 30,119 & 0.41 & 53.3 & 68.2 & 67.9 & 31.8 & 34.7 \\
\hline \multicolumn{8}{|l|}{ Lineage $D$} \\
\hline Ro-BatCoV HKU9 & 29,114 & 0.41 & 48.4 & 66.5 & 67.5 & 29.2 & 32.5 \\
\hline \multicolumn{8}{|l|}{ Gammacoronavirus } \\
\hline Infectious bronchitis virus & 27,608 & 0.38 & 42.1 & 60.6 & 60.2 & 24.8 & 28.0 \\
\hline BdCoV HKU22 & 31,750 & 0.39 & 45.3 & 60.0 & 58.2 & 25.7 & 28.9 \\
\hline \multicolumn{8}{|l|}{ Deltacoronavirus } \\
\hline BuCoV HKU11 & 26,476 & 0.39 & 38.5 & 51.2 & 47.5 & 26.4 & 23.8 \\
\hline PorCoV HKU15 & 25,421 & 0.43 & 38.8 & 51.8 & 48.6 & 26.0 & 23.1 \\
\hline $\begin{array}{l}\text { *The representative coronaviruses we } \\
\text { like protease; RdRp, RNA-dependent } \\
\text { SACoV, sable antelope CoV; SARS- } \\
\text { rousettus bat CoV; BdCoV, bottlenos }\end{array}$ & with comp & 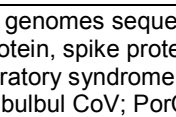 & availat & $\begin{array}{l}\text { oV, dro } \\
\text { capsid }\end{array}$ & $\begin{array}{l}\text { camel } \\
\mathrm{HCoV}\end{array}$ & $\begin{array}{l}\text { irus; } 3 \mathrm{CL}^{\mathrm{p}} \\
\mathrm{CoV} ; \mathrm{BC}\end{array}$ & $\begin{array}{l}\text { nymotrypsin- } \\
\text { oovine CoV; } \\
\text { atCoV, }\end{array}$ \\
\hline
\end{tabular}

Appendix Table 1, wwwnc.cdc.gov/EID/article/20/4/131769-Techapp1.pdf) (19,30).

The characteristics of putative NSPs in ORFlab of DcCoV UAE-HKU23 are shown in online Technical Appendix Table 2. The ORF1ab polyprotein shared $70.7 \%$ $99.3 \%$ aa identity with polyproteins of other betacoronavirus lineage A CoVs. The predicted putative cleavage sites were conserved between DcCoV UAE-HKU23 and other members of betacoronavirus A1 of the Betacoronavirus genus. The lengths of NSPs $1-3,13$, and 15 in DcCoV UAEHKU23 differed from those in equine $\mathrm{CoV}$, porcine hemagglutinating encephalomyelitis virus, and/or $\mathrm{HCoV}-\mathrm{OC} 43$ as a result of deletions/insertions.

The amino acid sequence of the predicted spike protein of DcCoV UAE-HKU23 is most similar to that of bovine coronavirus $(\mathrm{BCoV})$ and sable antelope $\mathrm{CoV}$, with which DcCoV UAE-HKU23 has $94.1 \%$ similarity (Table 2). A comparison of the amino acid sequences of DcCoV UAE-HKU23 spike protein and BCoV spike protein showed 81 aa polymorphisms, of which 24 were seen within the region previously identified as hypervariable among the spike protein of other betacoronavirus lineage A CoVs (31) (Figure 2); this finding suggests that this region in DcCoV UAE-HKU23 is also subject to strong immune selection. $\mathrm{BCoV}$ has been found to use $N$-acetyl9- $O$ acetyl neuramic acid as a receptor for initiation of infection (32). Among the 5 aa that may affect S1-mediated receptor binding in $\mathrm{BCoV}(31), 2$ aa (threonine at position 11 and glutamine at position 179) were conserved in
DcCoV UAE-HKU23 (Figure 2). However, at positions 115,118 , and 173, aspartic acid, methionine, and asparagine observed in $\mathrm{BCoV}$ and were replaced by serine, threonine, and histidine, respectively, in DcCoV UAEHKU23. A recent report identified 4 aa acids that were critical sugar-binding residues in the spike protein of $\mathrm{BCoV}$ (tyrosine, glutamic acid, tryptophan, and histidine at positions $162,182,184$, and 185 , respectively) (32); all 4 aa were also present in spike protein of DcCoV UAEHKU23 (Figure 2). Another study identified 7 aa substitutions in the spike protein of $\mathrm{BCoV}$ that differed between virulent and avirulent, cell culture-adapted strains (31); 5 of the 7 aa from virulent strains were also conserved in DcCoV UAE-HKU23, and amino acid substitutions were observed in the other 2 aa (threonine $\rightarrow$ valine at position 40 and aspartic acid $\rightarrow$ asparagine at position 470 ). It has also been reported that an amino acid change at position 531 of the spike protein of $\mathrm{BCoV}$ discriminated between enteric (aspartic acid/asparagine) and respiratory (glycine) strains (33). At this position, a threonine was conserved in all 3 genomes of DcCoV UAE-HKU23.

NS5 of DcCoV UAE-HKU23 shares $83.5 \%-98.2 \%$ aa identity with the corresponding NSPs of betacoronavirus A1 members. In murine hepatitis virus, translation of the envelope protein is cap-independent, through an internal ribosomal entry site $(19,30)$. However, a preceding transcription regulatory sequence, 5'-UCCAAAC-3', can be identified upstream of the envelope protein in $\mathrm{DcCoV}$ UAE-HKU23, as in other betacoronavirus A1 members 


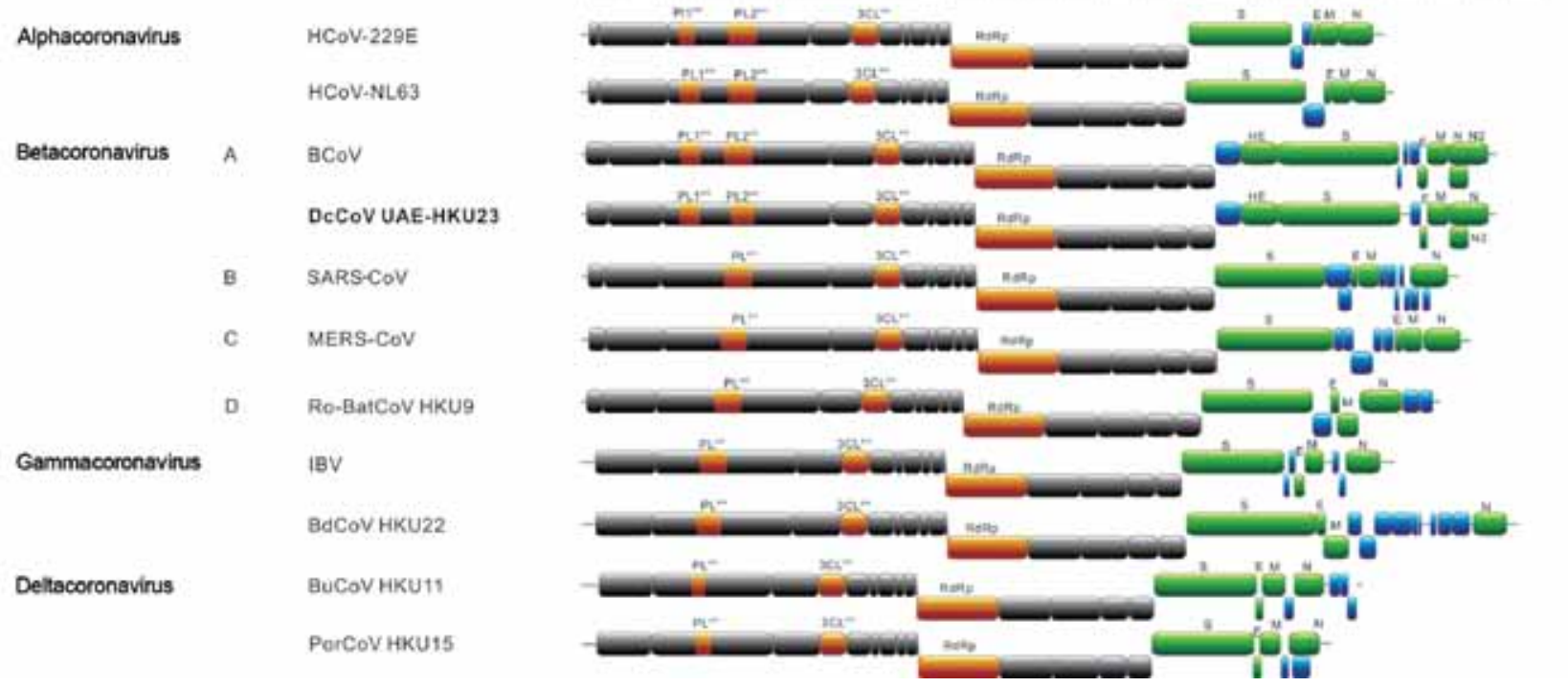

Figure 1. Genome organizations of a novel betacoronavirus, in boldface, discovered in dromedaries in the Middle East in 2013, and representative coronaviruses from each coronavirus genus (labeled on left). Numbers at top represent genome position. A, B, C, and $D$ represent betacoronavirus lineages. Papain-like proteases ( $P L 1^{\text {pro }}, P L 2^{\text {pro }}$, and $\left.P L^{\text {pro }}\right)$, chymotrypsin-like protease (3CL $\left.{ }^{\text {pro }}\right)$, and $R N A$ dependent RNA polymerase (RdRp) are represented by orange boxes. Hemagglutinin esterase (HE), spike (S), envelope (E), membrane $(\mathrm{M})$, and nucleocapsid $(\mathrm{N})$ proteins are represented by green boxes. Putative accessory proteins are represented by blue boxes. HCoV, human coronavirus; $\mathrm{BCoV}$, bovine $\mathrm{CoV}$; DcCoV, dromedary camel CoV; SARS-CoV, severe acute respiratory syndrome CoV; MERS-CoV, Middle East respiratory syndrome CoV; Ro-BatCoV, rousettus bat CoV; IBV, infectious bronchitis virus; BdCoV, bottlenose dolphin CoV; BuCoV, bulbul CoV; PorCoV, porcine CoV.

(Table 3; online Technical Appendix Table 1) (19,30). Downstream to nucleocapsid protein, the $3^{\prime}$-untranslated region contains a predicted bulged stem-loop structure of $68 \mathrm{nt}$ (nt position 30747-30814) that is conserved in betacoronaviruses (34). Overlapping with the bulged stem-loop structure by $5 \mathrm{nt}$, is a conserved pseudoknot structure (nt position 30810-30863) that is important for $\mathrm{CoV}$ replication.

\section{Phylogenetic Analyses}

Phylogenetic trees constructed by using the amino acid sequences of ORF1b polyprotein, spike protein, and

\begin{tabular}{|c|c|c|c|c|c|c|c|c|}
\hline \multirow[b]{2}{*}{ ORF } & \multicolumn{8}{|c|}{ Putative transcription regulatory sequence (distance, in bases, to AUG)† } \\
\hline & $\begin{array}{c}\text { DcCoV UAE- } \\
\text { HKU23 }\end{array}$ & BCoV & CRCoV & SACoV & GiCoV & PHEV & HCoV-OC43 & ECoV \\
\hline $1 \mathrm{ab}$ & $\begin{array}{c}\text { UCUAAAC } \\
(140)\end{array}$ & $\begin{array}{c}\text { UCUAAAC } \\
(140)\end{array}$ & $\begin{array}{l}\text { UCUAAAC } \\
\qquad(140)\end{array}$ & $\begin{array}{c}\text { UCUAAAC } \\
(140)\end{array}$ & $\begin{array}{c}\text { UCUAAAC } \\
(140)\end{array}$ & $\begin{array}{c}\text { UCUAAAC } \\
(140)\end{array}$ & $\begin{array}{c}\text { UCUAAAC } \\
(140)\end{array}$ & UCUAAAC (140) \\
\hline NS2 & $\begin{array}{l}\text { UCUAAAC } \\
\text { (7) }\end{array}$ & $\begin{array}{c}\text { UCUAAAC } \\
(7)\end{array}$ & $\begin{array}{l}\text { UCUAÁAC } \\
\text { (7) }\end{array}$ & $\begin{array}{c}\text { UCUAAAC } \\
\text { (7) }\end{array}$ & $\begin{array}{c}\text { UCUAAAC } \\
(7)\end{array}$ & $\begin{array}{l}\text { UCUAAAC } \\
\text { (1) }\end{array}$ & $\begin{array}{l}\text { UCUAAAC } \\
\text { (7) }\end{array}$ & UCUAAAA (12) \\
\hline $\mathrm{HE}$ & $\begin{array}{l}\text { ACUAAAC } \\
\text { (9) }\end{array}$ & $\begin{array}{c}\text { ACUAAAC } \\
(9)\end{array}$ & $\begin{array}{l}\text { ACUAAAC } \\
\text { (9) }\end{array}$ & $\begin{array}{c}\text { ACUAAAC } \\
\text { (9) }\end{array}$ & $\begin{array}{c}\text { ACUAAAC } \\
(9)\end{array}$ & $\begin{array}{c}\text { ACUAAAC } \\
\text { (9) }\end{array}$ & $\begin{array}{l}\text { AUUAAAC } \\
\text { (9) }\end{array}$ & UCUAAAC (9) \\
\hline S & $\begin{array}{l}\text { UCUAAAC } \\
(0)\end{array}$ & $\begin{array}{c}\text { UCUAAAC } \\
(0)\end{array}$ & $\begin{array}{c}\text { UCUAAAC } \\
\text { (0) }\end{array}$ & $\begin{array}{c}\text { UCUAAAC } \\
(0)\end{array}$ & $\begin{array}{c}\text { UCUAAAC } \\
(0)\end{array}$ & $\begin{array}{c}\text { UCUAAAC } \\
(0)\end{array}$ & $\begin{array}{l}\text { UCUAAAC } \\
(0)\end{array}$ & UCUAAAC $(0)$ \\
\hline NS5 & $\begin{array}{c}\text { GGUGAAC } \\
(51)\end{array}$ & $\begin{array}{c}\text { GGUAGAC } \\
(\mathbf{5 0})\end{array}$ & $\begin{array}{c}\text { GGUAGAC } \\
(51)\end{array}$ & $\begin{array}{c}\text { GGUAGAC } \\
(\mathbf{5 0})\end{array}$ & $\begin{array}{c}\text { GGUAGAC } \\
(\mathbf{5 0})\end{array}$ & $\begin{array}{c}\text { UUAAGCA } \\
(32)\end{array}$ & $\begin{array}{c}\text { UCUAGCA } \\
(20 / 32)\end{array}$ & $\begin{array}{l}\text { UAUACUUUAUAA } \\
(\mathbf{4 1})\end{array}$ \\
\hline $\mathrm{E}$ & $\begin{array}{l}\text { UCCAAAC } \\
(123)\end{array}$ & $\begin{array}{c}\text { UCCAAAC } \\
(123)\end{array}$ & $\begin{array}{c}\text { UCCAAAC } \\
(123)\end{array}$ & $\begin{array}{c}\text { UCCAAAC } \\
(123)\end{array}$ & $\begin{array}{c}\text { UCCAAAC } \\
(123)\end{array}$ & $\begin{array}{l}\text { UCCAAAC } \\
(123)\end{array}$ & $\begin{array}{l}\text { UCCAAAC } \\
(123)\end{array}$ & UCCAAAC (123) \\
\hline M & $\begin{array}{l}\text { UCCAAAC } \\
\text { (3) }\end{array}$ & $\begin{array}{l}\text { UCCAAAC } \\
\text { (3) }\end{array}$ & $\begin{array}{l}\text { UCCAAAC } \\
\text { (3) }\end{array}$ & $\begin{array}{l}\text { UCCAAAC } \\
\text { (3) }\end{array}$ & $\begin{array}{l}\text { UCCAAAC } \\
\text { (3) }\end{array}$ & $\begin{array}{l}\text { UCCAAAC } \\
\text { (3) }\end{array}$ & $\begin{array}{l}\text { UCCAAAC } \\
\text { (3) }\end{array}$ & UCCAAAC (3) \\
\hline $\mathrm{N}$ & $\begin{array}{c}\text { UCUAAAC } \\
(7)\end{array}$ & $\begin{array}{c}\text { UCUAAAC } \\
(7)\end{array}$ & $\begin{array}{c}\text { UCUAAAC } \\
(7)\end{array}$ & $\begin{array}{c}\text { UCUAAAC } \\
(7)\end{array}$ & $\begin{array}{c}\text { UCUAAAC } \\
(7)\end{array}$ & $\begin{array}{c}\text { UCUAAAC } \\
(7)\end{array}$ & $\begin{array}{l}\text { UCUAAAU } \\
(7)\end{array}$ & UCUAAAC (7) \\
\hline
\end{tabular}



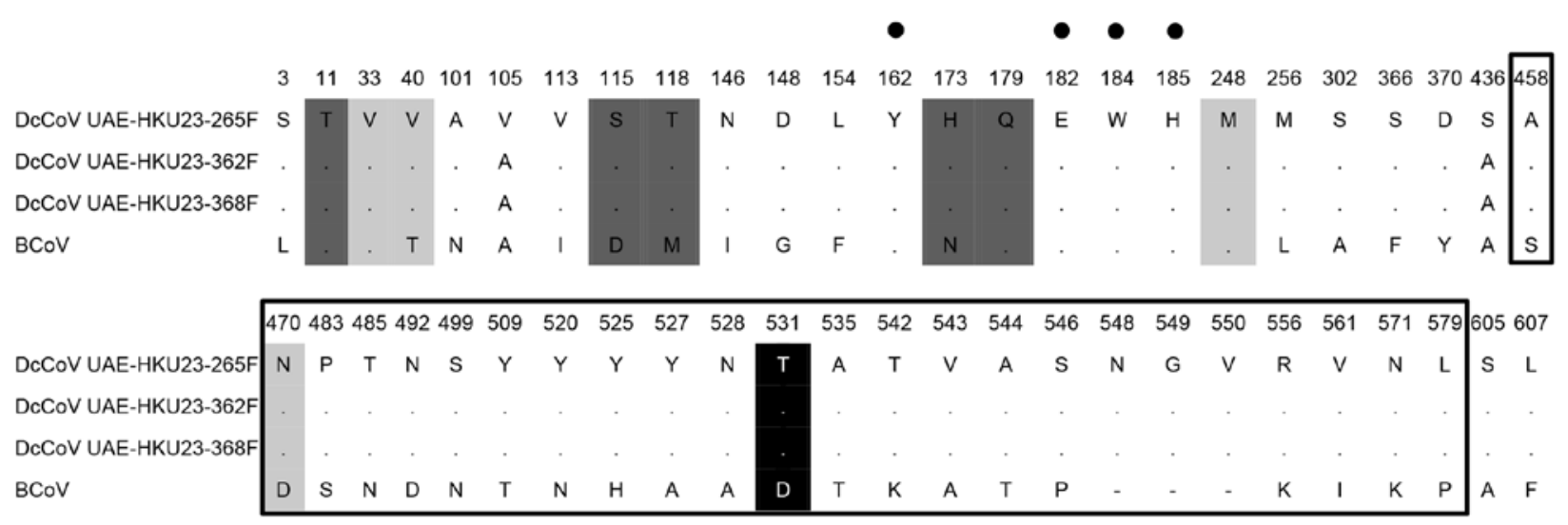

\begin{tabular}{|c|c|c|c|c|c|c|c|c|c|c|c|c|c|c|c|c|c|c|c|c|c|c|c|c|c|}
\hline & 611 & 625 & 643 & 710 & 721 & 724 & 726 & 746 & 747 & 761 & 765 & 766 & 767 & 768 & 769 & 770 & 771 & 772 & 788 & 789 & 830 & 845 & 865 & 880 & 913 \\
\hline DcCoV UAE-HKU23-265F & $G$ & A & $\mathrm{s}$ & V & A & V & $\mathrm{S}$ & 1 & A & $L$ & 1 & $\mathrm{D}$ & $\underline{R}$ & $\underline{R}$ & $\underline{\mathrm{S}}$ & $\underline{R}$ & $\underline{\mathrm{R}}$ & A & $\mathrm{K}$ & A & A & L & $F$ & A & A \\
\hline DcCoV UAE-HKU23-362F & . & . & . & . & . & . & . & . & . & . & . & . & . & . & . & . & . & . & . & . & . & V & . & . & $\cdot$ \\
\hline DcCoV UAE-HKU23-368F & . & . & . & . & . & . & . & . & . & . & . & . & . & . & . & . & . & . & . & . & . & V & . & . & \\
\hline $\mathrm{BCoV}$ & $D$ & $\mathrm{~s}$ & $T$ & I & S & $\mathrm{L}$ & $P$ & $\mathrm{~S}$ & V & V & $T$ & $\mathrm{~K}$ & . & & 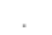 & - & - & $\mathrm{s}$ & $\mathrm{N}$ & $S$ & $\mathrm{~s}$ & V & $\mathrm{L}$ & V & \\
\hline
\end{tabular}

91592595196898810061029103310471058107210871163121512381240124412451292134413561365

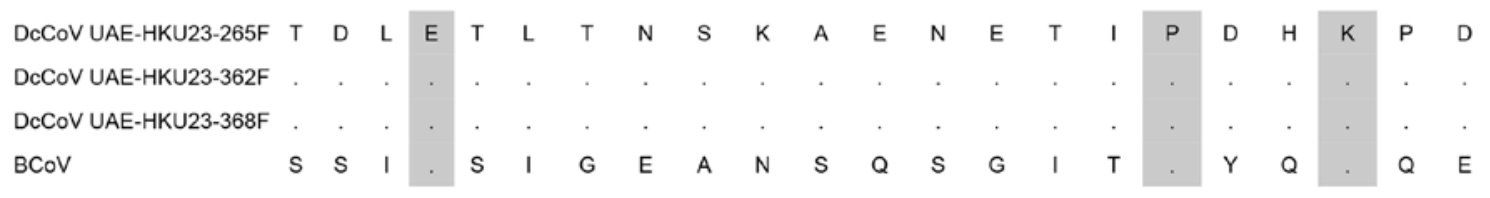

Figure 2. Amino acid comparison of the spike protein of a novel betacoronavirus, dromedary camel coronavirus (DcCoV) UAE-HKU23, discovered in dromedaries in the Middle East in 2013, with that of bovine coronavirus (BCoV; GenBank accession no. AF391541). Amino acid substitution sites, key amino acids for virulence and receptor binding in BCoV, and cleavage sites are shown. Amino acid positions are given with reference to DcCoV UAE-HKU23. Conserved amino acids, compared with those of DcCoV UAE-HKU23 (strain $265 \mathrm{~F}$ ), are represented by dots. Amino acids of putative cleavage sites are underlined. Amino acids within the S1 hypervariable region of BCoV are marked with open boxes. Amino acid sites central to virulence in BCoV are highlighted in light gray. Amino acid sites shown to affect $\mathrm{S} 1$-mediated receptor binding in $\mathrm{BCoV}$ are highlighted in dark gray. The 4 critical sugar-binding residues are indicated by black dots. The amino acid site that discriminated between enteric and respiratory BCoV strains is highlighted in black.

nucleocapsid protein of DcCoV UAE-HKU23 and other CoVs are shown in Figures 3-5. The pairwise amino acid identities of chymotrypsin-like protease (3CL $\left.{ }^{\text {ro }}\right)$, RdRp, helicase, spike protein, and nucleocapsid protein are shown in Table 2. In all 3 phylogenetic trees, DcCoV UAEHKU23 clustered with other members of betacoronavirus $\mathrm{A} 1$, including $\mathrm{BCoV}$, sable antelope $\mathrm{CoV}$, equine $\mathrm{CoV}$, $\mathrm{HCoV}-\mathrm{OC} 43$, giraffe $\mathrm{CoV}$, porcine hemagglutinating encephalomyelitis virus, canine respiratory $\mathrm{CoV}$, and rabbit $\mathrm{CoV}$ (RbCoV) HKU14 (Figures 3-5).

\section{Antibody Detection}

Nucleocapsid protein of DcCoV UAE-HKU23 was purified. Prominent immunoreactive bands were visible for $31(52 \%)$ of 59 dromedary serum samples; 25 of the 31 samples had titers of 2,000 , three had titers of 4,000 , and 3 had titers of 8,000 (Figure 6). Serum samples for all 4 adult dromedaries were positive for DcCoV UAE-HKU23 antibodies, and 27 (49\%) of the 55 samples for teenage dromedaries were positive. Band sizes were $\approx 50 \mathrm{kDa}$, consistent with the expected size of $50.4 \mathrm{kDa}$ for the full-length (His) $)_{6}$-tagged recombinant nucleocapsid protein. Only very faint bands were observed when the 3 serum samples positive for DcCoV UAE-HKU23 antibodies were incubated with nucleocapsid proteins of SARS-CoV, Pi-BatCoV HKU5, or Ro-BatCoV HKU9, indicating minimal crossreactivity. This finding concurs with our previous observation that minimal cross-reactivity occurs between CoVs in different lineages in betacoronavirus (16). For MERS-CoV antibody testing, results were positive for 57 (97\%) of the 59 samples by Western blot analysis, for all 59 samples by indirect immunofluorescence, and for 58 (98\%) of the 59 samples by neutralization antibody test (Table 4).

\section{Estimation of Substitution Rates and Divergence Dates}

The $K a, K s$, and $K a / K s$ of the various coding regions in DcCoV UAE-HKU23 are shown in Table 5. 

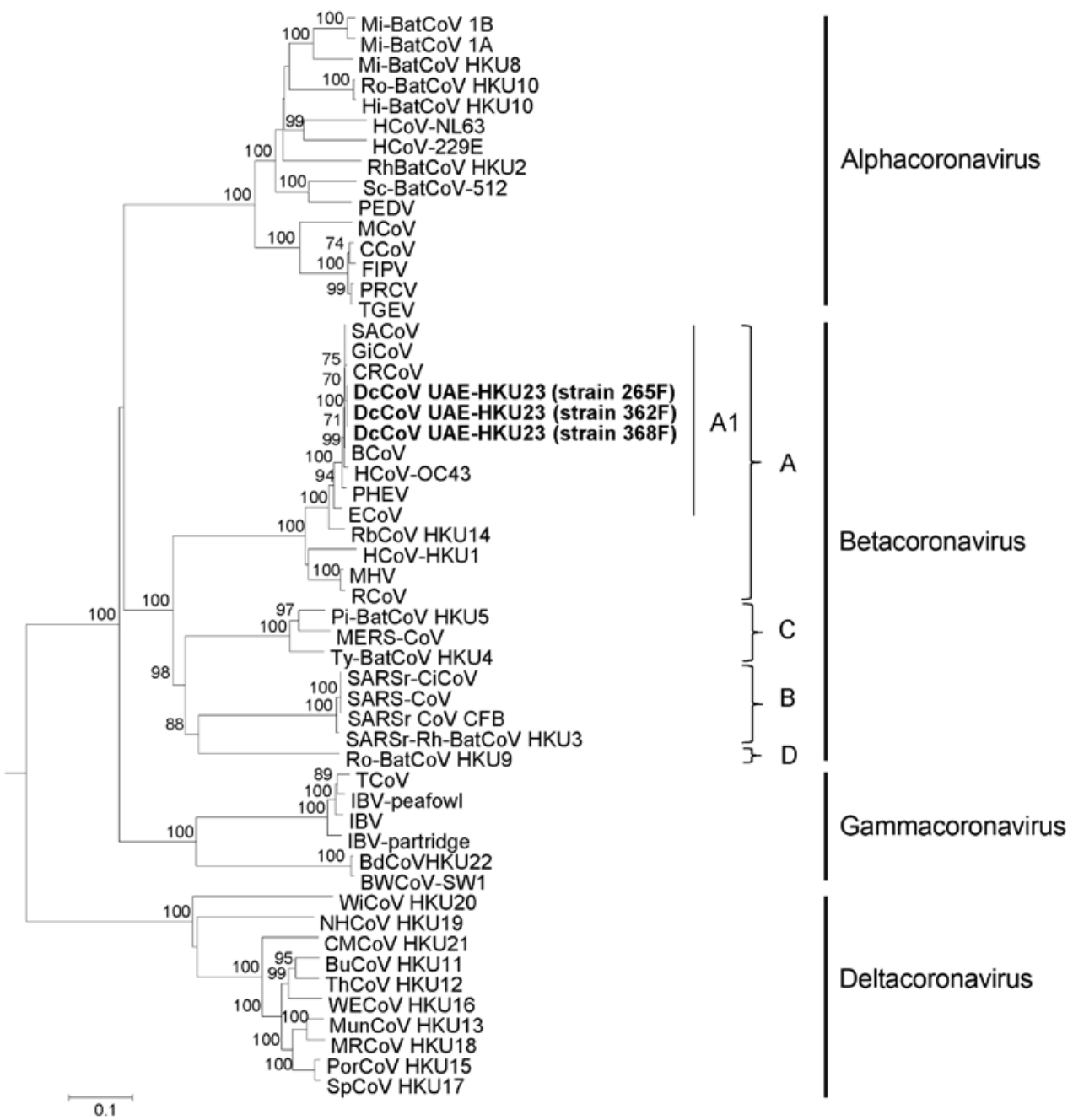

Figure 3. Phylogenetic analysis of open reading frame (ORF) $1 \mathrm{~b}$ polyprotein of dromedary camel coronavirus (DcCoV) UAE-HKU23 from dromedaries of the Middle East, 2013. The tree was constructed by the neighbor-joining method, using Jones-Taylor-Thornton substitution model with gamma distributed rate variation and bootstrap values calculated from 1,000 trees. Bootstrap values of $<70 \%$ are not shown. A total of 2,725 aa positions in ORF1b polyprotein were included in the analysis. The tree was rooted to Breda virus (GenBank accession no. AY_427798). Betacoronavirus lineages A1 and A-D are indicated on the right. Boldface indicates the 3 strains of DcCoV UAE-HKU23 characterized in this study. Virus definitions and GenBank accession numbers (in parentheses) follow: Mi-BatCoV 1B, miniopterus bat CoV 1B (NC_010436); Mi-BatCoV 1A (NC_010437); Mi-BatCoV HKU8 (NC_010438); Ro-BatCoV HKU10, rousettus bat CoV HKU10 (JQ989270); Hi-BatCoV HKU10, hipposideros bat CoV HKU10 (JQ989266); HCoV-NL63, human CoV NL63 (NC_005831); HCoV-229E (NC_002645); RhBatCoV HKU2, rhinolophus bat CoV HKU2 (EF203064); Sc-BatCoV-512, scotophilus bat CoV 512 (NC_009657); PEDV, porcine epidemic diarrhea virus (NC_003436); MCoV, mink CoV (HM245925); CCoV, canine CoV (GQ477367); FIPV, feline infectious peritonitis virus (AY994055); PRCV, porcine respiratory CoV; TGEV, transmissible gastroenteritis virus; SACoV, sable antelope CoV; GiCoV, giraffe CoV (EF424622); CRCoV, canine respiratory CoV (JX860640); BCoV, bovine CoV (NC_003045); HCoV-OC43, human CoV OC43 (NC_005147); PHEV, porcine hemagglutinating encephalomyelitis virus (NC_007732); ECoV, equine CoV (NC_010327); RbCoV HKU14, rabbit CoV HKU14 (JN874559); HCoV-HKU1, human CoV HKU1 (NC_006577); MHV, murine hepatitis virus (NC_001846); RCoV, rat CoV (NC_012936); Pi-BatCoV HKU5, pipistrellus bat CoV HKU5 (NC_009020); MERS-CoV, Middle East respiratory syndrome CoV (JX869059); Ty-BatCoV HKU4, tylonycteris bat CoV HKU4 (NC_009019); SARSr-CiCoV, SARS-related palm civet CoV (AY304488); SARS-CoV, severe acute respiratory syndrome-associated human CoV (NC_004718); SARSrCoV CFB, SARS-related Chinese ferret badger CoV (AY545919); SARS-related rhinolophus bat CoV HKU3 (DQ022305); Ro-BatCoV HKU9, rousettus bat CoV HKU9 (NC_009021); TCoV, turkey CoV (NC_010800); IBV-peafowl, peafowl CoV (AY641576); IBV, infectious bronchitis virus (NC_001451); IBV-partridge, partridge CoV (AY646283); BdCoV HKU22, bottlenose dolphin CoV HKU22 (KF793824); BWCoV-SW1, Beluga whale CoV SW1 (NC_010646); WiCoV HKU20, wigeon CoV HKU20 (JQ065048); NHCoV HKU19, night-heron CoV HKU19 (JQ065047); CMCoV HKU21, common-moorhen CoV HKU21 (JQ065049); BuCoV HKU11, bulbul CoV HKU11 (FJ376619); ThCoV HKU12, thrush CoV HKU12 (FJ376621); WECoV HKU16, white-eye CoV HKU16 (JQ065044); MunCoV HKU13, munia CoV HKU13 (FJ376622); MRCoV HKU18, magpie-robin CoV HKU18 (JQ065046); PorCoV HKU15, porcine CoV HKU15 (JQ065042); SpCoV HKU17, sparrow CoV HKU17 (JQ065045). Numbers at nodes represent bootstrap values. Scale bar indicates the estimated number of substitutions per 10 aa. 


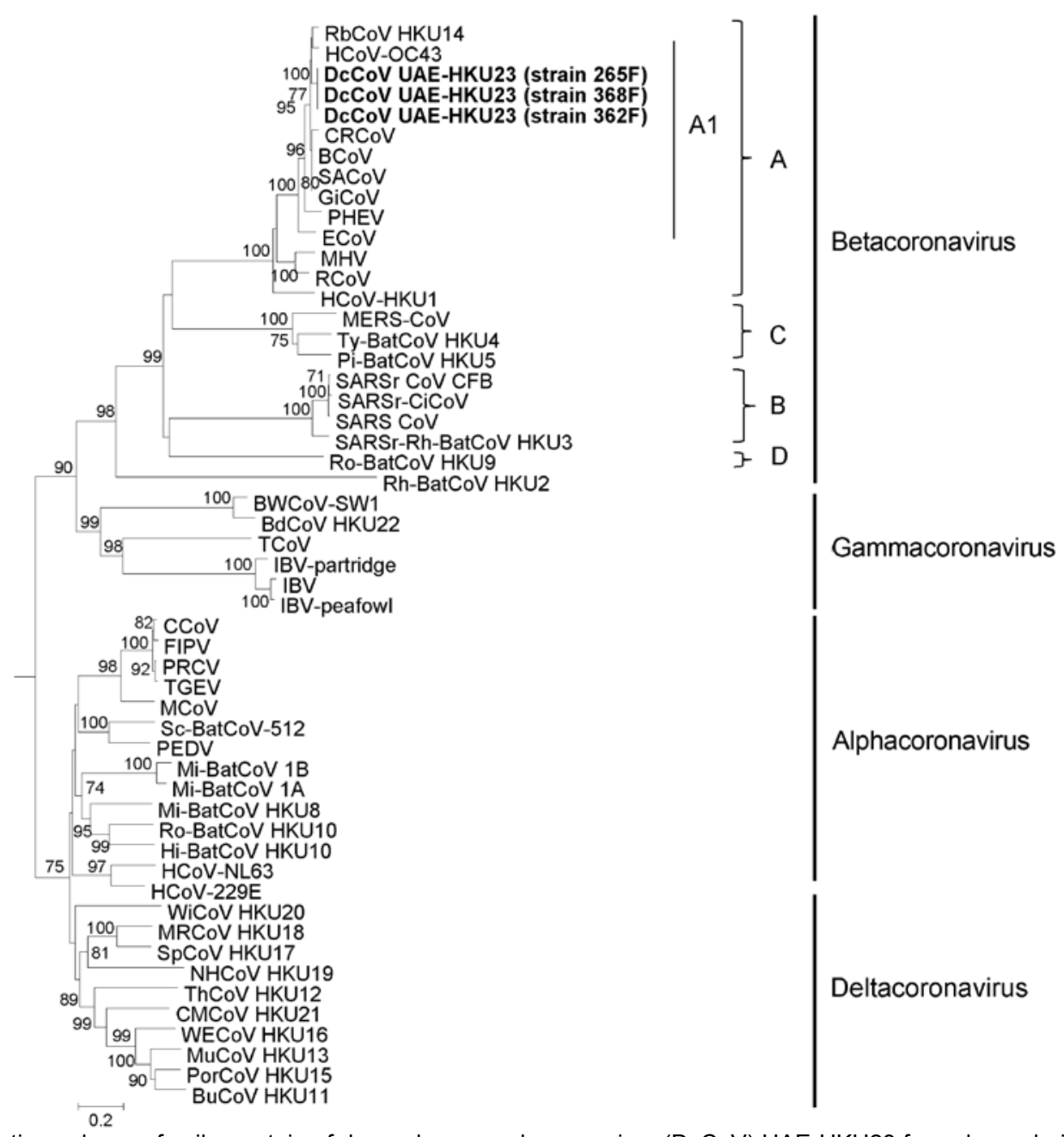

Figure 4. Phylogenetic analyses of spike protein of dromedary camel coronavirus (DcCoV) UAE-HKU23 from dromedaries of the Middle East, 2013. The tree was constructed by the neighbor-joining method, using Jones-Taylor-Thornton substitution model with gamma distributed rate variation and bootstrap values calculated from 1,000 trees. Bootstrap values of $<70 \%$ are not shown. A total of 1,366 aa positions in spike protein were included in the analysis. The tree was rooted to Breda virus (GenBank accession no. AY_427798). Betacoronavirus lineages $\mathrm{A} 1$ and A-D are indicated on the right. Boldface indicates the 3 strains of DcCoV UAE-HKU23 characterized in this study. Virus definitions and GenBank accession numbers (in parentheses) follow: RbCoV HKU14, rabbit CoV HKU14 (JN874559); HCoV-OC43, human CoV OC43 (NC_005147); CRCoV, canine respiratory CoV (JX860640); BCoV, bovine CoV (NC_003045); SACoV, sable antelope CoV (EF424621); GiCoV, giraffe CoV (EF424622); PHEV, porcine hemagglutinating encephalomyelitis virus (NC_007732); ECoV, equine CoV (NC_010327); MHV, murine hepatitis virus (NC_001846); RCoV, rat CoV (NC_012936); HCoV-HKU1, human CoV HKU1 (NC_006577); MERS-CoV, Middle East respiratory syndrome CoV (JX869059); Ty-BatCoV HKU4, tylonycteris bat CoV HKU4 (NC_009019); Pi-BatCoV HKU5, pipistrellus bat CoV HKU5 (NC_009020); SARSrCoV CFB, SARS-related Chinese ferret badger CoV (AY545919); SARSr-CiCoV, SARS-related palm civet CoV (AY304488); SARS-CoV, severe acute respiratory syndrome-associated human CoV (NC_004718); SARSr-Rh-BatCoV HKU3, SARS-related rhinolophus bat CoV HKU3 (DQ022305); Ro-BatCoV HKU9, rousettus bat CoV HKU9 (NC_009021); RhBatCoV HKU2, rhinolophus bat CoV HKU2 (EF203064); BWCoV-SW1, Beluga whale CoV SW1 (NC_010646); BdCoV HKU22, bottlenose dolphin CoV HKU22 (KF793824); TCoV, turkey CoV (NC_010800); IBV-partridge, partridge CoV (AY646283); IBV, infectious bronchitis virus (NC_001451); IBV-peafowl, peafowl CoV (AY641576); CCoV, canine CoV (GQ477367); FIPV, feline infectious peritonitis virus (AY994055); PRCV, porcine respiratory CoV (DQ811787); TGEV, transmissible gastroenteritis virus (DQ811789); MCoV, mink CoV (HM245925); Sc-BatCoV-512, scotophilus bat CoV 512 (NC_009657); PEDV, porcine epidemic diarrhea virus (NC_003436); Mi-BatCoV 1B, miniopterus bat CoV 1B (NC_010436); Mi-BatCoV 1A, miniopterus bat CoV 1A (NC_010437); MiBatCoV HKU8, miniopterus bat CoV HKU8 (NC_010438); Ro-BatCoV HKU10, rousettus bat CoV HKU10 (JQ989270); Hi-BatCoV HKU10, hipposideros bat CoV HKU10 (JQ989266); HCoV-NL63, human CoV NL63 (NC_005831); HCoV-229E, human CoV 229E (NC_002645); WiCoV HKU20, wigeon CoV HKU20 (JQ065048); MRCoV HKU18, magpie-robin CoV HKU18 (JQ065046); SpCoV HKU17, sparrow CoV HKU17 (JQ065045); NHCoV HKU19, night-heron CoV HKU19 (JQ065047); ThCoV HKU12, thrush CoV HKU12 (FJ376621); CMCoV HKU21, common-moorhen CoV HKU21 (JQ065049); WECoV HKU16, white-eye CoV HKU16 (JQ065044); MunCoV HKU13, munia CoV HKU13 (FJ376622); PorCoV HKU15, porcine CoV HKU15 (JQ065042); BuCoV HKU11, bulbul CoV HKU11 (FJ376619). Numbers at nodes represent bootstrap values. Scale bar indicates the estimated number of substitutions per 5 aa. 

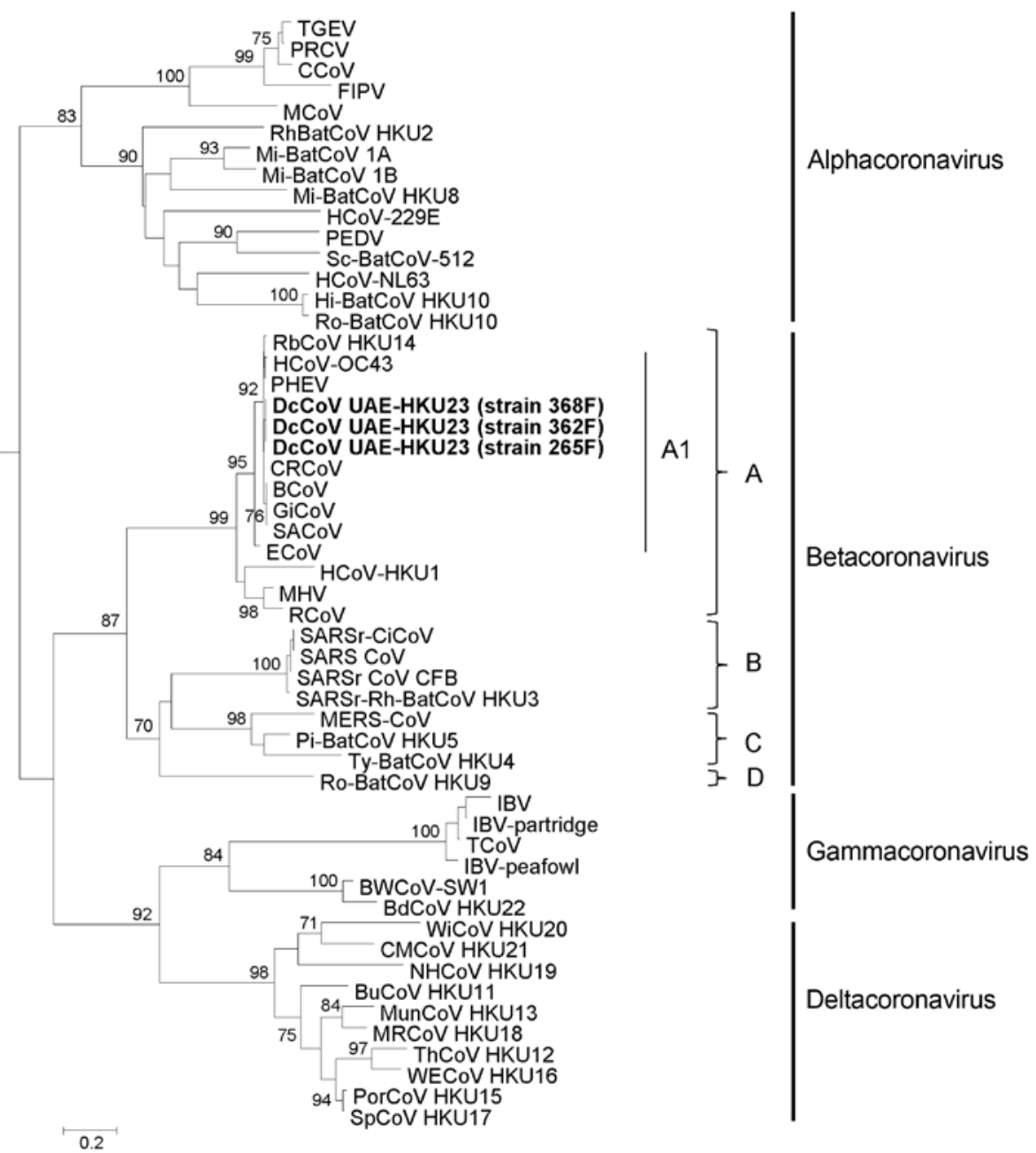

Figure 5. Phylogenetic analyses of the nucleocapsid protein of a novel coronavirus (CoV), dromedary camel CoV (DcCoV) UAE-HKU23, discovered in dromedaries of the Middle East, 2013. The tree was constructed by the neighbor-joining method, using Jones-TaylorThornton substitution model with gamma distributed rate variation and bootstrap values calculated from 1,000 trees. Bootstrap values of $<70 \%$ are not shown. A total of 448 aa positions were included in the analysis. The tree was rooted to Breda virus (GenBank accession no. AY 427798). Betacoronavirus lineages A1 and A-D are indicated on the right. Boldface indicates the 3 strains of DcCoV UAEHKU23 characterized in this study. Virus definitions and GenBank accession numbers (in parentheses) follow: TGEV, transmissible gastroenteritis virus (DQ811789); PRCV, porcine respiratory CoV (DQ811787); CCoV, canine CoV (GQ477367); FIPV, feline infectious peritonitis virus (AY994055); MCoV, mink CoV (HM245925); RhBatCoV HKU2, rhinolophus bat CoV HKU2 (EF203064); Mi-BatCoV 1A, miniopterus bat CoV 1A (NC_010437); Mi-BatCoV 1B, miniopterus bat CoV 1B (NC_010436); Mi-BatCoV HKU8, miniopterus bat CoV HKU8 (NC_010438); HCoV-229E, human CoV 229E (NC_002645); PEDV, porcine epidemic diarrhea virus (NC_003436); Sc-BatCoV-512, scotophilus bat CoV 512 (NC_009657); HCoV-NL63, human CoV NL63 (NC_005831); Hi-BatCoV HKU10, hipposideros bat CoV HKU10 (JQ989266); Ro-BatCoV HKU10, rousettus bat CoV HKU10 (JQ989270); RbCoV HKU14, rabbit CoV HKU14 (JN874559); HCoV-OC43, human CoV OC43 (NC_005147); PHEV, porcine hemagglutinating encephalomyelitis virus (NC_007732); CRCoV, canine respiratory CoV (JX860640); BCoV, bovine CoV (NC_003045); GiCoV, giraffe CoV (EF424622); SACoV, sable antelope CoV (EF424621); ECoV, equine CoV (NC_010327); HCoV-HKU1, human CoV HKU1 (NC_006577); MHV, murine hepatitis virus (NC_001846); RCoV, rat CoV (NC 012936); SARSr-CiCoV, SARS-related palm civet CoV (AY304488); SARS-CoV, severe acute respiratory syndrome-associated human CoV (NC_004718); SARSrCoV CFB, SARS-related Chinese ferret badger CoV (AY545919); SARSr-Rh-BatCoV HKU3, SARSrelated rhinolophus bat CoV HKU3 (DQ022305); MERS-CoV, Middle East respiratory syndrome CoV (JX869059); Pi-BatCoV HKU5, pipistrellus bat CoV HKU5 (NC_009020); Ty-BatCoV HKU4, tylonycteris bat CoV HKU4 (NC_009019); Ro-BatCoV HKU9, rousettus bat CoV HKU9 (NC_009021); IBV, infectious bronchitis virus (NC_001451); IBV-partridge, partridge CoV (AY646283); TCoV, turkey CoV (NC 010800); IBV-peafowl, peafowl CoV (AY641576); BWCoV-SW1, Beluga whale CoV SW1 (NC 010646); BdCoV HKU22, bottlenose dolphin CoV HKU22 (KF793824); WiCoV HKU20, wigeon CoV HKU20 (JQ065048); CMCoV HKU21, common-moorhen CoV HKU21 (JQ065049); NHCoV HKU19, night-heron CoV HKU19 (JQ065047); BuCoV HKU11, bulbul CoV HKU11 (FJ376619); MunCoV HKU13, munia CoV HKU13 (FJ376622); MRCoV HKU18, magpie-robin CoV HKU18 (JQ065046); ThCoV HKU12, thrush CoV HKU12 (FJ376621); WECoV HKU16, white-eye CoV HKU16 (JQ065044); PorCoV HKU15, porcine CoV HKU15 (JQ065042); SpCoV HKU17, sparrow CoV HKU17 (JQ065045). Numbers at nodes represent bootstrap values. Scale bar indicates the estimated number of substitutions per 5 aa. 


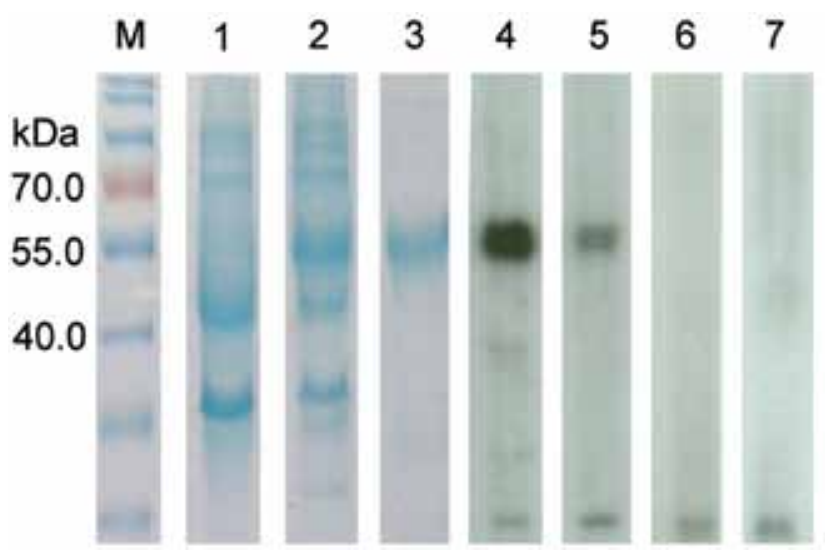

Figure 6. Sodium dodecyl sulfate-polyacrylamide gel electrophoresis and Western blot analysis of a novel coronavirus, dromedary camel coronavirus UAE-HKU23, discovered in dromedaries of the Middle East, 2013. Nucleocapsid protein was expressed in Escherichia coli. $\mathrm{M}$, protein molecular-mass marker; $\mathrm{kDa}$, kilodaltons. Lanes: 1 , noninduced crude $E$. coli cell lysate; 2 , induced crude $E$. coli cell lysate of DcCoV UAE-HKU23 nucleocapsid protein; 3, purified recombinant DcCoV UAE-HKU23 nucleocapsid protein; 4, dromedary camel serum sample strongly positive for antibody against nucleocapsid protein; 5 , dromedary camel serum sample moderately positive for antibody against nucleocapsid protein; 6 and 7: dromedary camel serum sample negative for antibody against nucleocapsid protein.

The $K a / K s$ of all the coding regions in DcCoV UAEHKU23 was $\leq 0.5$.

By using the uncorrelated relaxed clock model on RdRp gene sequences, we estimated the date of divergence between DcCoV UAE-HKU23 and BCoV to be $\approx 46$ years ago. We estimated that the 3 strains of DcCoV UAEHKU23 diverged from their most recent common ancestor in March 2010 (the $95 \%$ highest posterior density interval, August 2006-September 2012) (online Technical Appendix Figure 1).

\section{Discussion}

We discovered a novel $\mathrm{CoV}$, but no MERS-CoV, in dromedaries from the Middle East. Dromedaries are 1 of 2 surviving camel species. Dromedaries (C. dromedarius; 1-humped camels) inhabit the Middle East and northern and northeastern Africa; Bactrian camels (C. bactrianus, 2-humped camels) inhabit Central Asia. Among the 20 million camels on earth, $90 \%$ are dromedaries. In 2012, there were $\approx 360,000$ dromedaries in the United Arab Emirates.

In this study, we discovered a novel CoV, DcCoV UAE-HKU23, from $4.8 \%$ of 293 fecal samples collected from dromedaries in Dubai. The positive samples were not collected from the same farm or stable. Moreover, there was $>0.2 \%$ nt difference among the 3 complete genomes sequenced, indicating that the positive samples were not collected from a clonal outbreak. In our study, $21.3 \%$ of dromedary calves, but only $0.4 \%$ of adult dromedaries, were RT-PCR positive for DcCoV UAE-HKU23; this finding indicates that dromedary calves are probably more susceptible than adult dromedaries to infection with DcCoV UAE-HKU23. Furthermore, DcCoV UAE-HKU23 is probably stably evolving in dromedaries because the $\mathrm{Ka} /$ $K s$ of all the coding regions in the genome were $\leq 0.5$. In this study, 4 of the 12 positive samples were collected from dromedaries with diarrhea. A previous report also described the presence of a betacoronavirus in the fecal sample of a dromedary calf with diarrhea (35). This finding raises the question of the pathologic significance of DcCoV UAEHKU23 for camelids and warrants further animal studies.

Our serologic data showed little cross-reactivity between DcCoV UAE-HKU23 and SARS-CoV, Pi-BatCoV HKU5, and Ro-BatCoV HKU9. This finding is in line with findings from our previous studies of Ro-BatCoV HKU9, which also showed minimal serologic cross-reactivity among the 4 lineages of betacoronaviruses (16). These results suggest that there should be minimal crossreactivity between DcCoV UAE-HKU23 and MERS$\mathrm{CoV}$, which belong to 2 different $\mathrm{CoV}$ lineages. Because we showed an extremely high prevalence of MERS-CoV antibodies in the serum samples by Western blot analysis, indirect immunofluorescence, and neutralization antibody testing, concurring with findings in a previous study (24), we would also expect a similar high prevalence of DcCoV UAE-HKU23 antibodies if there was major serologic cross-reactivity between MERS-CoV and DcCoV UAE-HKU23. However, our serologic data only revealed the presence of DcCoV UAE-HKU23 antibodies in 52\% of the serum samples, indicating that no correlation exists between seropositivity to DcCoV UAE-HKU23 and seropositivity to MERS-CoV. Furthermore, we found no correlation between seropositivity to DcCoV UAE-HKU23 and MERS-CoV antibody titers.

In this study, correlation between DcCoV UAEHKU23 RT-PCR positivity and seropositivity also

\begin{tabular}{lc}
\hline $\begin{array}{l}\text { Table 4. Detection of antibodies to MERS-CoV in dromedaries in } \\
\text { the Middle East, 2013* }\end{array}$ \\
\hline \multicolumn{1}{l}{ Test, antibody titer } & No. (\%) positive samples \\
\hline Indirect immunofluorescence & \\
160 & $2(3.4)$ \\
320 & $12(20.3)$ \\
640 & $16(27.1)$ \\
1280 & $11(18.6)$ \\
2560 & $14(23.7)$ \\
5120 & $4(6.8)$ \\
\hline Neutralization antibody test & \\
$<10$ & $1(1.7)$ \\
10 & $7(11.9)$ \\
20 & $14(23.7)$ \\
40 & $28(47.5)$ \\
80 & $8(13.6)$ \\
160 & $1(1.7)$ \\
${ }^{*}$ MERS-CoV, Middle East respiratory syndrome coronavirus.
\end{tabular}


Table 5. Estimates of nonsynonymous and synonymous substitution rates in the genomes of a novel betacoronavirus, DcCoV UAE-HKU23, discovered in dromedaries of the Middle East, 2013*

\begin{tabular}{lccc}
\hline Gene & Ka & $K s$ & $K a / K s$ \\
\hline NSP1 & 0 & 0.004 & 0 \\
NSP2 & 0 & 0.002 & 0 \\
NSP3 & 0.001 & 0.006 & 0.167 \\
NSP4 & 0.001 & 0.007 & 0.143 \\
NSP5 & 0.001 & 0.003 & 0.333 \\
NSP6 & 0.001 & 0.003 & 0.333 \\
NSP7 & 0 & 0 & - \\
NSP8 & 0 & 0.016 & 0 \\
NSP9 & 0 & 0 & - \\
NSP10 & 0 & 0 & - \\
NSP11 & 0 & 0 & - \\
NSP12 & 0 & 0.002 & 0 \\
NSP13 & 0 & 0.002 & 0 \\
NSP14 & 0.001 & 0 & - \\
NSP15 & 0.001 & 0 & - \\
NSP16 & 0 & 0 & - \\
NS2 & 0.001 & 0.008 & 0.125 \\
HE & 0.001 & 0.002 & 0.5 \\
Spike & 0.001 & 0.004 & 0.25 \\
NS5 & 0 & 0.009 & 0 \\
Envelope & 0 & 0 & - \\
Membrane & 0 & 0 & - \\
Nucleocapsid & 0 & 0 & - \\
N2 & 0 & 0 & - \\
\hline DcCoV, dromedary camel coronavirus; Ka, nonsynonymous site; Ks, \\
synonymous site; NSP, nonstructural protein; NS, nonstructural; HE, \\
hemagglutinin esterase; N, nucleocapsid. & & \\
\hline & \multicolumn{3}{c}{} \\
\hline
\end{tabular}

cannot be ascertained because the fecal samples and serum samples were collected from different dromedaries. Because MERS-CoV was not present in dromedaries in the present study, an intensive search in dromedaries and other animals in other locations in the Middle East would be helpful in the search for the animal source of MERS-CoV.
DcCoV UAE-HKU23 is a member of betacoronavirus A1 (Figure 7). Comparison of the amino acid identities of the 7 conserved replicase domains for species demarcation (i.e., ADP-ribose 1"-phosphatase, NSP5 [3CL pro $]$, NSP12 [RdRp], NSP13 [helicase], NSP14 [ExoN], NSP15 [NendoU], and NSP16 [O-MT]) (36) between DcCoV UAEHKU23 and other CoVs of betacoronavirus A1 revealed that in all 7 domains, the amino acid sequences of DcCoV UAE-HKU23 and other betacoronavirus A1 members shared $>90 \%$ identity. This finding indicates that $\mathrm{DcCoV}$ UAE-HKU23 should be a member of betacoronavirus A1.

Furthermore, the genome characteristics of DcCoV UAE-HKU23 showed features similar to those of other betacoronavirus A1 members. The genomes of all betacoronavirus $\mathrm{A} 1$ members have $\mathrm{G}+\mathrm{C}$ contents of 0.37 and the genome of RbCoV HKU14, a recently discovered $\mathrm{CoV}$ closely related to betacoronavirus A1 (19), has a $\mathrm{G}+\mathrm{C}$ content of 0.38 . This $\mathrm{G}+\mathrm{C}$ content differs substantially from those of other $\mathrm{CoV}$ species of lineage A betacoronaviruses, which have $\mathrm{G}+\mathrm{C}$ contents of 0.32 (HCoV-HKU1), 0.41 (rat CoV) and 0.42 (murine hepatitis virus) (Table 2). The difference in the genome characteristics between A1 and non-A1 members of betacoronavirus is also reflected by their codon usage bias, in which the general preference of using $\mathrm{G} / \mathrm{C}$ in the third position of the codons decreases from murine hepatitis virus and rat $\mathrm{CoV}$ to betacoronavirus A1 members and RbCoV HKU14 to HCoV-HKU1 (online Technical Appendix Figure 2). The cleavage site for spike protein of betacoronavirus A1 members is RRS/QRR, whereas those of $\mathrm{HCoV}-\mathrm{HKU} 1, \mathrm{RbCoV} \mathrm{HKU} 14$, and murine hepatitis virus are RRKRR, LRSRR, and RAR/H/ $\mathrm{DR} / \mathrm{S}$, respectively. The length of membrane genes for betacoronavirus A1 members and RbCoV HKU14 is 693

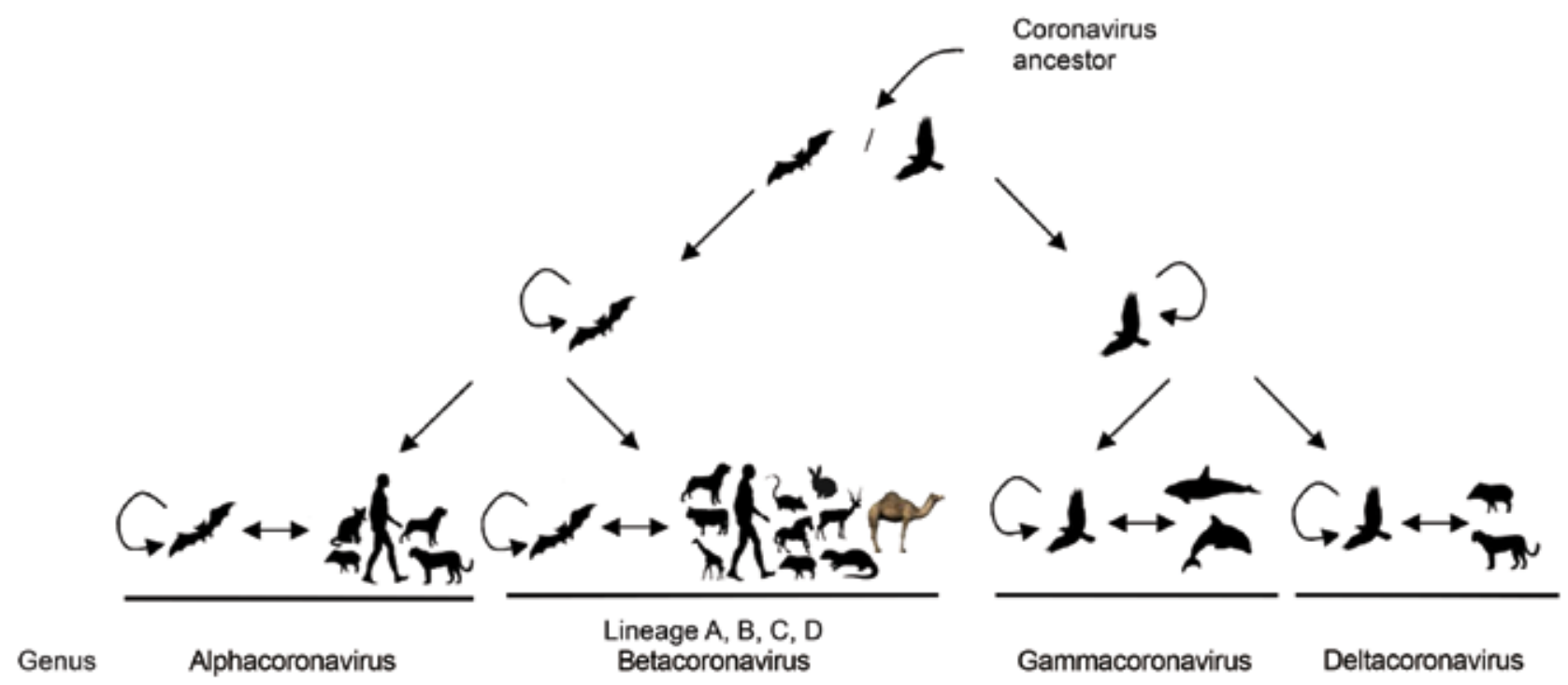

Figure 7. The evolution of coronaviruses from their ancestors in bat and bird hosts to new virus species that infect other animals. 
bases, whereas the lengths for HCoV-HKU1 and murine hepatitis virus are 672 and 687 bases, respectively.

DcCoV UAE-HKU23 is phylogenetically closely related to other betacoronavirus A1 members, which in turn are closely related to other $\mathrm{CoVs}$ of betacoronavirus lineage A. Despite their close relationships, no recombination was detected between DcCoV UAE-HKU23 and other betacoronavirus A1 members by bootscan analysis (data not shown). These CoVs of betacoronavirus A1 may be using different receptors in their corresponding hosts because their spike protein is one of the proteins that show the largest difference among different CoVs. Most of the differences among the spike proteins in different betacoronavirus $\mathrm{A} 1$ members were also observed in the $\mathrm{N}$ terminal half of their spike protein, where the receptor binding domains should be located.

Camels are one of the most unique mammals on earth. In particular, they have shown perfect adaptation to desert life, which presents temperature extremes and a scarce supply of food and water. In the past, camels were used for transportation of humans and goods and for military uses. Moreover, for humans, they provide a good source of meat, milk, and wool. Camels are also important recreational animals in the Middle East and are used for camel racing. Having been associated with humans for at least 5,000 years, camels usually pose little physical danger to humans. However, infectious pathogens, such as brucellosis, can occasionally be transmitted from camels to humans. Apart from the present novel $\mathrm{CoV}$, viruses of at least 8 taxonomic families (i.e., Paramyxoviridae, Flaviviridae, Herpesviridae, Papillomaviridae, Picornaviridae, Poxviridae, Reoviridae, and Rhabdoviridae) have been found to infect camels (37-39). Because camels are closely associated with humans, continuous surveillance of viruses in this hardy group of animals is needed to understand the potential for virus emergence and transmission to humans.

\section{Acknowledgments}

We thank Wing-Man Ko and Constance Chan for their continuous support.

This work is partly supported by the Hong Kong Special Administrative Region Health and Medical Research Fund; Seed Funding for TRS and Strategic Research Theme Fund, The University of Hong Kong; Theme-based Research Scheme, Research Grant Council Grant, University Grant Council; and Consultancy Service for Enhancing Laboratory Surveillance of Emerging Infectious Disease for the Hong Kong Special Administrative Region Department of Health.

Dr Woo is a professor and head of the Department of Microbiology at The University of Hong Kong. His research focuses on novel microbe discovery and microbial genomics.

\section{References}

1. Guan Y, Zheng BJ, He YQ, Liu XL, Zhuang ZX, Cheung CL, et al. Isolation and characterization of viruses related to the SARS coronavirus from animals in southern China. Science. 2003;302:276-8. http://dx.doi.org/10.1126/science.1087139

2. Woo PC, Lau SK, Tsoi HW, Chan KH, Wong BH, Che XY, et al. Relative rates of non-pneumonic SARS coronavirus infection and SARS coronavirus pneumonia. Lancet. 2004;363:841-5. http://dx.doi.org/10.1016/S0140-6736(04)15729-2

3. Cheng VC, Lau SK, Woo PC, Yuen KY. Severe acute respiratory syndrome coronavirus as an agent of emerging and reemerging infection. Clin Microbiol Rev. 2007;20:660-94. http://dx.doi. org/10.1128/CMR.00023-07

4. van derHoek L, Pyrc K, Jebbink MF, Vermeulen-Oost W, BerkhoutRJ, Wolthers $\mathrm{KC}$, et al. Identification of a new human coronavirus. Nat Med. 2004;10:368-73. http://dx.doi.org/10.1038/nm1024

5. Woo PC, Lau SK, Chu CM, Chan KH, Tsoi HW, Huang Y, et al. Characterization and complete genome sequence of a novel coronavirus, coronavirus HKU1, from patients with pneumonia. J Virol. 2005;79:884-95. http://dx.doi.org/10.1128/JVI.79.2.884-895.2005

6. Woo PC, Lau SK, Tsoi HW, Huang Y, Poon RW, Chu CM, et al. Clinical and molecular epidemiological features of coronavirus HKU1-associated community-acquired pneumonia. J Infect Dis. 2005;192:1898-907. http://dx.doi.org/10.1086/497151

7. Lau SK, Woo PC, Yip CC, Tse H, Tsoi HW, Cheng VC, et al. Coronavirus HKU1 and other coronavirus infections in Hong Kong. J Clin Microbiol. 2006;44:2063-71. http://dx.doi.org/10.1128/JCM.02614-05

8. Lau SK, Woo C, Li KS, Huang Y, Tsoi HW, Wong BH, et al. Severe acute respiratory syndrome coronavirus-like virus in Chinese horseshoe bats. Proc NatlAcad Sci U S A. 2005;102:14040-5. http://dx.doi.org/10.1073/pnas.0506735102

9. Li W, Shi Z, Yu M, Ren W, Smith C, Epstein JH, et al. Bats are natural reservoirs of SARS-like coronaviruses. Science. 2005;310:6769. http://dx.doi.org/10.1126/science.1118391

10. Ge XY, Li JL, Yang XL, Chmura AA, Zhu G, Epstein JH, et al. solation and characterization of a bat SARS-like coronavirus that uses the ACE2 receptor. Nature. 2013;503:535-8. http://dx.doi. org/10.1038/nature12711

11. Woo PC, Lau SK, Li S, Poon RW, Wong BH, Tsoi HW, et al. Molecular diversity of coronaviruses in bats. Virology. 2006;351:180-7. http://dx.doi.org/10.1016/j.virol.2006.02.041

12. Woo PC, Wang M, Lau SK, Xu H, Poon RW, Guo R, et al. Comparative analysis of twelve genomes of three novel group $2 \mathrm{c}$ and group $2 \mathrm{~d}$ coronaviruses reveals unique group and subgroup features. J Virol. 2007;81:1574-85. http://dx.doi.org/10.1128/JVI.02182-06

13. Lau SK, Woo PC, Li KS, Huang Y, Wang M, Lam CS, et al. Complete genome sequence of bat coronavirus HKU2 from Chinese horseshoe bats revealed a much smaller spike gene with a different evolutionary lineage from the rest of the genome. Virology. 2007;367:428-39. http://dx.doi.org/10.1016/j.virol.2007.06.009

14. Woo PC, Lau SK, Lam CS, Lai KK, Huang Y, Lee P, et al. Comparative analysis of complete genome sequences of three avian coronaviruses reveals a novel group 3c coronavirus. J Virol. 2009;83:908-17. http://dx.doi.org/10.1128/JVI.01977-08

15. Lau SK, LiK S, Huang Y, Shek CT, Tse H, Wang M, et al. Ecoepidemiology and complete genome comparison of different strains of severe acute respiratory syndrome-related Rhinolophus bat coronavirus in China reveal bats as a reservoir for acute, self-limiting infection that allows recombination events. J Virol. 2010;84:280819. http://dx.doi.org/10.1128/JVI.02219-09

16. Lau SK, Poon RW, Wong BH, Wang M, Huang Y, Xu H, et al. Coexistence of different genotypes in the same bat and serological characterization of Rousettus bat coronavirus HKU9 belonging to a novel Betacoronavirus subgroup. J Virol. 2010;84:11385-94. http://dx.doi.org/10.1128/JVI.01121-10 
17. Lau SK, Li KS, Tsang AK, Shek CT, Wang M, Choi GK, et al. Recent transmission of a novel alphacoronavirus, bat coronavirus HKU10, from Leschenault's rousettes to pomona leaf-nosed bats: first evidence of interspecies transmission of coronavirus between bats of different suborders. J Virol. 2012;86:11906-18. http://dx.doi. org/10.1128/JVI.01305-12

18. Woo PC, Lau SK, Lam CS, Lau CC, Tsang AK, Lau JH, et al. Discovery of seven novel mammalian and avian coronaviruses in the genus Deltacoronavirus supports bat coronaviruses as the gene source of Alphacoronavirus and Betacoronavirus and avian coronaviruses as the gene source of Gammacoronavirus and Deltacoronavirus. J Virol. 2012;86:3995-4008. http://dx.doi.org/10.1128/ JVI.06540-11

19. Lau SK, Woo PC, Yip CC, Fan RY, Huang Y, Wang M, et al. Isolation and characterization of a novel Betacoronavirus subgroup A coronavirus, rabbit coronavirus HKU14, from domestic rabbits. J Virol. 2012;86:5481-96. http://dx.doi.org/10.1128/JVI.06927-11

20. Woo PC, Lau SK, Lam CS, Tsang AK, Hui SW, Fan RY, et al. Discovery of a novel bottlenose dolphin coronavirus reveals a distinct species of marine mammal coronavirus in Gammacoronavirus. J Virol. 2014;88:1318-31. http://dx.doi.org/10.1128/JVI.02351-13

21. Zaki AM, van Boheemen S, Bestebroer TM, Osterhaus AD, Fouchier RA. Isolation of a novel coronavirus from a man with pneumonia in Saudi Arabia. N Engl J Med. 2012;367:1814-20. http://dx.doi.org/10.1056/NEJMoa1211721

22. de Groot RJ, Baker SC, Baric RS, Brown CS, Drosten C, Enjuanes L, et al. Middle East respiratory syndrome coronavirus (MERS-CoV): announcement of the Coronavirus Study Group. J Virol. 2013;87:7790-2. http://dx.doi.org/10.1128/JVI.01244-13

23. Lau SK, Li KS, Tsang AK, Lam CS, Ahmed S, Chen H, et al. Genetic characterization of Betacoronavirus lineage $\mathrm{C}$ viruses in bats reveals marked sequence divergence in the spike protein of Pipistrellus bat coronavirus HKU5 in Japanese pipistrelle: implications for the origin of the novel Middle East respiratory syndrome coronavirus. J Virol. 2013;87:8638-50. http://dx.doi.org/10.1128/JVI.01055-13

24. Reusken CB, Haagmans BL, Muller MA, Gutierrez C, Godeke GJ, Meyer B, et al. Middle East respiratory syndrome coronavirus neutralising serum antibodies in dromedary camels: a comparative serological study. Lancet Infect Dis. 2013;13:859-66. http://dx.doi. org/10.1016/S1473-3099(13)70164-6

25. Huang Y, Lau SK, Woo PC, Yuen KY. CoVDB: a comprehensive database for comparative analysis of coronavirus genes and genomes. Nucleic Acids Res. 2008;36:D504-11. http://dx.doi. org/10.1093/nar/gkm754

26. Tamura K, Peterson D, Peterson N, Stecher G, Nei M, Kumar S. MEGA5: molecular evolutionary genetics analysis using maximum likelihood, evolutionary distance, and maximum parsimony methods. Mol Biol Evol. 2011;28:2731-9. http://dx.doi.org/10.1093/ molbev/msr121

27. Lau SK, Lau CC, Chan KH, Li CP, Chen H, Jin DY, et al. Delayed induction of proinflammatory cytokines and suppression of innate antiviral response by the novel Middle East respiratory syndrome coronavirus: implications for pathogenesis and treatment. J Gen Virol. 2013;94:2679-90. http://dx.doi.org/10.1099/vir.0.055533-0
28. Chan KH, Chan JF, Tse H, Chen H, Lau CC, Cai JP, et al. Crossreactive antibodies in convalescent SARS patients' sera against the emerging novel human coronavirus EMC (2012) by both immunofluorescent and neutralizing antibody tests. J Infect. 2013;67:130 40. http://dx.doi.org/10.1016/j.jinf.2013.03.015

29. Drummond AJ, Rambaut A. BEAST: Bayesian evolutionary analysis by sampling trees. BMC Evol Biol. 2007;7:214. http://dx.doi. org/10.1186/1471-2148-7-214

30. Lau SK, Lee P, Tsang AK, Yip CC, Tse H, Lee RA, et al. Molecular epidemiology of human coronavirus OC43 reveals evolution of different genotypes over time and recent emergence of a novel genotype due to natural recombination. J Virol. 2011;85:11325-37. http://dx.doi.org/10.1128/JVI.05512-11

31. Chouljenko VN, Kousoulas KG, Lin X, Storz J. Nucleotide and predicted amino acid sequences of all genes encoded by the $3^{\prime}$ genomic portion $(9.5 \mathrm{~kb})$ of respiratory bovine coronaviruses and comparisons among respiratory and enteric coronaviruses. Virus Genes. 1998;17:33-42. http://dx.doi. org/10.1023/A:1008048916808

32. Peng G, Xu L, Lin YL, Chen L, Pasquarella JR, Holmes KV, et al. Crystal structure of bovine coronavirus spike protein lectin domain. J Biol Chem. 2012;287:41931-8. http://dx.doi.org/10.1074/jbc.M112.418210

33. Yoo D, Deregt D. A single amino acid change within antigenic domain II of the spike protein of bovine coronavirus confers resistance to virus neutralization. Clin Diagn Lab Immunol. 2001;8:297-302.

34. Goebel SJ, Hsue B, Dombrowski TF, Masters PS. Characterization of the RNA components of a putative molecular switch in the $3^{\prime}$ untranslated region of the murine coronavirus genome. J Virol. 2004;78:669-82. http://dx.doi.org/10.1128/JVI.78.2.669-682.2004

35. Wünschmann A, Frank R, Pomeroy K, Kapil S. Enteric coronavirus infection in a juvenile dromedary (Camelus dromedarius). J Vet Diagn Invest. 2002;14:441-4. http://dx.doi.org/ $10.1177 / 104063870201400518$

36. de Groot RJ, Baker SC, Baric R, Enjuanes L, Gorbalenya A, Holmes KV, et al. Coronaviridae. In: King AMQ, Adams MJ, Carstens EB, Lefkowitz EJ, editors. Virus taxonomy, classification and nomenclature of viruses. Ninth report of the International Committee on Taxonomy of Viruses. San Diego: Elsevier Academic Press; 2011. pp. 806-28.

37. Wernery $U$, Zachariah R. Experimental camelpox infection in vaccinated and unvaccinated dromedaries. Zentralbl Veterinarmed B. 1999;46:131-5.

38. Wernery U, Kaaden OR. Foot-and-mouth disease in camelids: a review. Vet J. 2004;168:134-42. http://dx.doi.org/10.1016/j. tvj1.2003.10.005

39. Wernery U, Knowles NJ, Hamblin C, Wernery R, Joseph S, Kinne $\mathrm{J}$, et al. Abortions in dromedaries (Camelus dromedarius) caused by equine rhinitis A virus. J Gen Virol. 2008;89:660-6. http://dx.doi.org/10.1099/vir.0.82215-0

Address for correspondence: Patrick C.Y. Woo, State Key Laboratory of Emerging Infectious Diseases, Department of Microbiology, University of Hong Kong, University Pathology Bldg, Queen Mary Hospital, Hong Kong, China; email: pcywoo@hkucc.hku.hk

\section{Emerging Infectious Diseases Journal Podcasts \\ Reginald Tucker reads an abridged version of the EID journal's Another Dimension, Zombies-A Pop Culture Resource for Public Health Awareness} http://www2c.cdc.gov/podcasts/player.asp?f $=8628220$ 